\title{
Survey of farmers' knowledge of cassava mosaic disease and their preferences for cassava cultivars in three agro-ecological zones in Benin
}

Jerome Anani Houngue ${ }^{1^{*}}$ (D), Justin S. Pita ${ }^{2}$, Gilles Habib Todjro Cacaï ${ }^{1}$, Martine Zandjanakou-Tachin ${ }^{3}$, Emmanuel A. E. Abidjo ${ }^{1}$ and Corneille Ahanhanzo ${ }^{1}$

\begin{abstract}
Background: Cassava is an important crop in Africa that is widely cultivated for its starchy tuberous root, which constitutes a major source of dietary carbohydrates. Cassava mosaic disease (CMD) is the most devastating disease affecting cassava in Africa and causes enormous losses in yield. In Benin, specifically, cultivars resistant to CMD are not commonly planted, and even when CMD is observed in fields, farmers do not implement control measures, presumably because they lack proper knowledge and training. Our study aimed to evaluate farmers' knowledge of CMD to determine whether there is consistency between farmers' criteria for selecting cassava cultivars and the currently CMD-recommended cassava varieties.

Methods: We conducted structured interviews with 369 farmers in 20\% of townships in each of three agro-ecological zones in Benin between November 2015 and February 2016. Farmers were selected randomly in each household, and their fields were assessed for CMD incidence and severity.

Results: All farmers surveyed, representing a broad demographic pool with regard to education level, age group, and years of experience in cassava production, successfully recognized CMD symptoms in photos, but most (98.60\%) said they did not know the causes and vectors of the disease. Most farmers (93.51\%) reported that they obtain planting material from neighboring fields or their own fields. In total, 52 unique cultivars were identified, of which 3 (5.76\%) were preferred based on their yield and precocity and 3 (5.76\%) were preferred based on taste or ability for transformation. The assessment of disease incidence and severity showed that the areas most affected by CMD were Comè Township (37.77\% of fields affected) and agro-ecological zone VIII (26.33\%).

Conclusion: Farmers already know how to recognize the symptoms of CMD and could implement control measures against it if they are trained by researchers. Across all surveyed areas, we identified six preferred cultivars based on the four most commonly stated preference criteria (precocity, yield, gari, and taste. Our results suggest that farmers will be more likely to use CMD-resistant cultivars and clean plant material if the plants meet their existing preference criteria. We suggest that CMD-resistant cultivars will be embraced only if the recommended cultivars are strategically aligned with the characteristics desirable to the cassava farmers in each region.
\end{abstract}

Keywords: Farmer survey, Preferred cultivars, Cassava mosaic disease, Disease severity, Disease symptoms, Staple crop, Knowledge evaluation, Manihot esculenta

\footnotetext{
* Correspondence: hounanje@gmail.com

${ }^{1}$ Central Laboratory of Plant Biotechnology and Plant Breeding, Department of Genetics and Biotechnology, Faculty of Science and Technique, University of Abomey - Calavi, Abomey-Calavi, Benin

Full list of author information is available at the end of the article
}

(c) The Author(s). 2018 Open Access This article is distributed under the terms of the Creative Commons Attribution 4.0 International License (http://creativecommons.org/licenses/by/4.0/), which permits unrestricted use, distribution, and reproduction in any medium, provided you give appropriate credit to the original author(s) and the source, provide a link to the Creative Commons license, and indicate if changes were made. The Creative Commons Public Domain Dedication waiver (http://creativecommons.org/publicdomain/zero/1.0/) applies to the data made available in this article, unless otherwise stated. 


\section{Background}

Cassava (Manihot esculenta Crantz) is one of the most important food crops in sub-Saharan Africa. Every part of the plant can be eaten; the starchy roots are by far the most commonly used because they are a valuable source of energy and can be boiled or processed in different ways for human consumption [1]. The leaves and tender shoots are a rich source of proteins and vitamins and are consumed as a vegetable in many regions [2]. Two advantages of cassava compared with other food crops are the flexibility in its planting and harvest times and its tolerance to drought [3]; it can survive and produce high yields in conditions that cereal crops would fail [4]. In Benin, cassava is the second most commonly grown crop after maize. Cassava is the most important crop in multi-crop systems, it is found in a wide range of markets, and it provides a stable source of income and food; thus, it is a form of food security for many households.

Cassava mosaic disease (CMD) is the most devastating cassava disease in Africa, causing annual yield losses of 1223 million tons, which is equivalent to $\$ 1.2$ to 2.3 billion USD [5]. CMD is caused by cassava mosaic geminiviruses (family Geminiviridae, genus Begomovirus), which are transmitted by the whitefly vector, Bemisia tabaci (order Hemiptera, family Aleyrodidae), and through the use of infected cuttings during vegetative propagation [6-8]. CMD symptoms are present in most cassava fields, and the disease affects many cultivars in Benin. Farmers are urged to adopt resistant varieties and cultivars, but successful adoption is dependent on the presence of preferred traits among the available cultivars. Sometimes, the recommended varieties are rejected by farmers because they do not correspond with farmers' preferences. Preferences such as taste, yield, and transformation ability of cassava have typically been ignored when screening cassava germplasm for CMD resistance [9]. We predicted that the failure to integrate CMD-resistant cassava cultivars in Benin is the result of the characters not matching the characteristics that are most desirable to small-scale farmers. We further predicted that the reason CMD is not controlled properly in Benin is that small-scale farmers lack proper knowledge and training. (For example, we have previously observed that some farmers in this region think that they can control the virus using pesticides.) In this study, we conducted a large-scale survey in Benin to gather vital information about farmers' preferences for cassava cultivars and their knowledge of CMD. This participatory approach aimed to reveal the potential social constraints to the adoption of CMD-resistant cassava varieties $[8,10]$ in Benin. The study's specific aims were as follows: (1) to evaluate famers' knowledge of CMD, (2) identify the local cassava varieties being cultivated by farmers, and (3) understand the cultivar characteristics that farmers prefer. Knowledge about how viruses are transmitted and their infection cycle is important to control the spread of the disease, as no approved or reliable antiviral products are generally available. When managed poorly, CMD and other viruses can cause a complete loss of cassava yields; it is

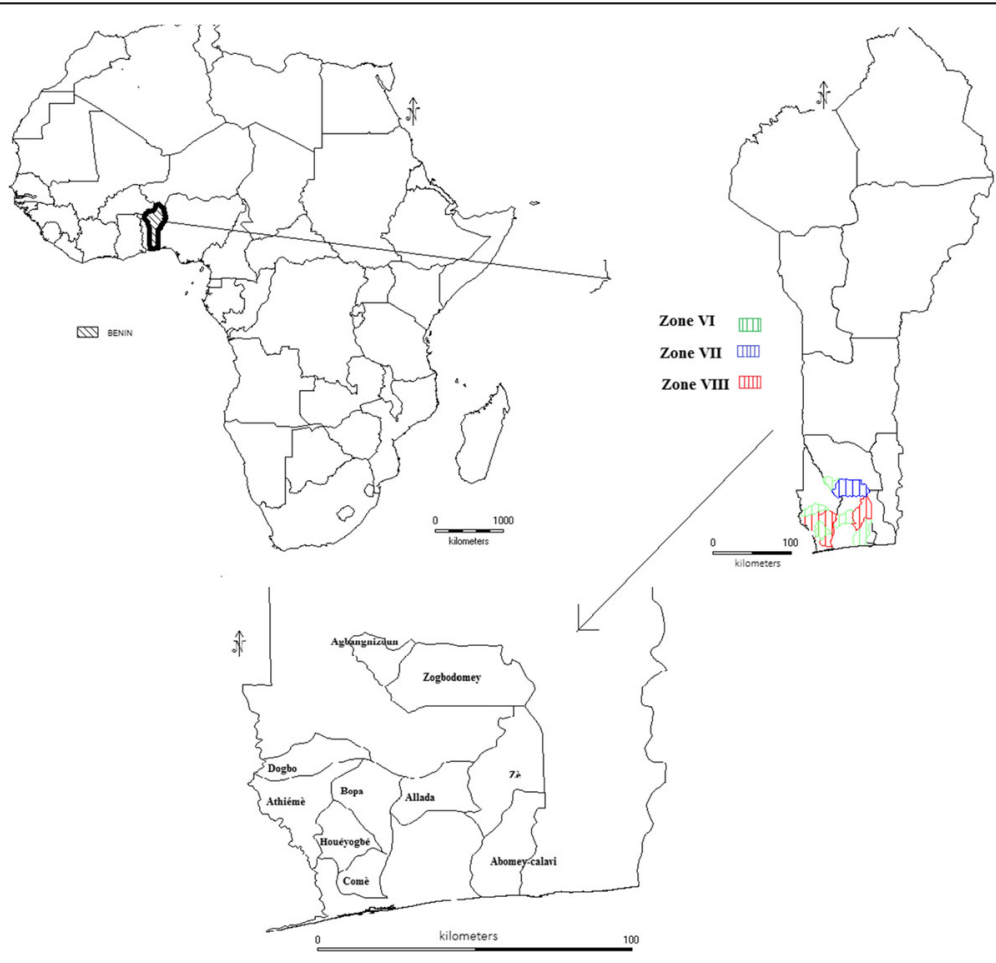

Fig. 1 Map of survey areas in three agro-ecological zones in Benin 
therefore important to understand what farmers know about CMD, their perceptions about how infection affects cassava yields, how they currently manage the disease, their criteria for selecting cassava cultivars, and how they source planting materials. Building knowledge among farmers is probably the most important strategy for controlling CMD, and the first step in building this knowledge is to understand the current state of farmers' knowledge.

\section{Methods}

\section{Areas surveyed}

The study was conducted in three agro-ecological zones (AEZ) in Benin: AEZ VI (Zone of Bar Land), AEZ VII (Zone of Fishery), and AEZ VIII (Zone of Depression) where cassava is either the primary crop or the secondary crop (after maize) [11]. We selected five townships from AEZ VI (Houéyogbé, Abomey-calavi, Dogbo-tota, and Zè, Agbangnizoun), three townships from AEZ VII (Come, Bopa, and Athieme), and one from from AEZ VIII (Zogbodomè) (Fig. 1). These areas are characterized by a SudanoGuinean climate and have a bimodal rainfall pattern between 800 and $1400 \mathrm{~mm}$ annually, with two distinct rainy seasons and two dry periods.

\section{Sampling and data collection}

Information on farmers' knowledge of CMD was collected using semi-structured questionnaires; the state of cultivars in their fields was assessed by conducting field observations. A multi-stage sampling method was used to select farmers to participate to interviews. In the first stage, we selected $20 \%$ of the townships in each AEZ based on their relative importance in cassava production. Five townships were selected in AEZ VI, three in AEZ VII, and one in AEZ VIII. In the second stage, we randomly sampled three villages per township, for a total of 27 villages (Fig. 1). In the third stage, we randomly sampled 15 to 20 households per village. The sample size (total number of surveys) was determined by applying the Dagnelie formula [12]:

$$
N=\frac{\cup_{1-\alpha / 2}^{2} * P(1-P)}{d^{2}}
$$

where $N$ is the sample size; $\mathrm{U}_{1-} \quad / 2$ is the reduced centered variable number $=1.96 ; P$ is the proportion of interviewed farmers who recognized CMD symptoms on photos

Table 1 Sample size (number of farmers surveyed) by agroecological zone

\begin{tabular}{ll}
\hline Agro-ecological zone (AEZ) & Sample size \\
\hline AEZVI & 219 \\
AEZ VIII & 45 \\
AEZ VII & 105 \\
Total & 369 \\
\hline
\end{tabular}

according to what they saw in their farm; and $d$ is the margin of error set at $5 \%$. The application of this formula gives $N=369$ farmers, of which 219 were in AEZ VI, 105 were in AEZ VII, and 45 were in AEZ VIII (Table 1).

The identification of responding households was facilitated by rural development officials (RDRs) and sometimes by village leaders. The questionnaires were tested during a pre-survey on 30 farmers in three AEZ, which allowed the research team to optimize their techniques to survey the farmers. Two kinds of questions were asked to farmers: closed (yes/no) questions and openended questions that gave farmers the freedom to give their opinions [13]. All interviews were conducted in the local language of the villages (Fon, Mina, Sahouè, Adja, and Nago) to encourage farmers to explain confidently their views. The assessment of farmers' knowledge of CMD was done with photographs of plants exhibiting CMD symptoms or infested with insect pests as described by Chikoti et al. [8]. Some questions in the questionnaire were rephrased to enable farmers to better understand and respond as fully as possible. To evaluate farmers' criteria in their selection of cassava cultivars, we used the survey method described by Dansi et al. [14]. Briefly, farmers were asked to list the characteristics that a cassava cultivar must have in order to be widely adopted in their village. They were then asked to rank these selection criteria according to their importance.

\section{Incidence and severity of CMD}

Field surveys were carried out in nine townships to establish the correlation between farmers' knowledge of CMD and the incidence and severity of CMD in their township. For this purpose, three cassava fields

Table 2 Socio-demographic characteristics of respondents

\begin{tabular}{lll}
\hline Socio-demographic characteristics & Modality & Percentages \\
\hline Experience in production & $\leq 15$ years & 0.3 \\
& $15-30$ years & 33.5 \\
& $>30$ years & 66.2 \\
Sex & Male & 62.4 \\
Age & Female & 37.6 \\
& $\leq 15$ years & 0 \\
& 15-30 years & 5.9 \\
Marital status & $>30$ years & 94.1 \\
& Married & 96.5 \\
& Single & 3 \\
Education & Widow(er) & 0.6 \\
& No schooling & 74.9 \\
& Primary & 10.3 \\
& Secondary & 11.6 \\
& Tertiary & 3.2 \\
\hline
\end{tabular}


Table 3 Chi-squared tests to investigate whether farmers' knowledge of CMD differed by socio-demographic factors

\begin{tabular}{llll}
\hline Factors & $x^{2}$ & ddl & $P$ \\
\hline Sex & 1.65 & 1 & $0.20 \mathrm{NS}$ \\
Age & 0.89 & 1 & $0.45 \mathrm{NS}$ \\
Experience & 0.10 & 2 & $0.96 \mathrm{NS}$ \\
Education & 3.64 & 3 & $0.30 \mathrm{NS}$ \\
\hline
\end{tabular}

$d d l$ degree of liberty, $P$ probability, NS not significant at $5 \%$ threshold

containing plants grown for 3 months at least $15 \mathrm{~km}$ apart [15] were surveyed in each township. We selected and scored 30 plants along two diagonals of the field using the CMD scale described by Hahn et al. [16]. Disease incidence was determined by dividing the number of infected plants by the total number of observed plants. Classes of disease severity were constructed based on the Hahn scale [16], and the townships were grouped according to these classes using principal component analysis (PCA).

\section{Analysis and data processing}

Survey data was processed with Sphinx Statistical Processing Software (version 4.5). Farmers were grouped according to five categories: socio-cultural group, age, education level, years of experience growing cassava, and gender (Table 2). A frequency distribution was plotted to compare the response rates for each category. Chisquared tests were used to test for relationships between farmers' knowledge of CMD and the five categories. Separate chi-squared tests were used to test whether a farmer's preferences for a particular cultivar were related to the region in which they lived and whether these characteristics were present in their preferred cultivars.

The most commonly grown cultivars were considered "preferred," and we ran a correspondence analysis (CA) to group preferred cultivars by criterion of choice. Disease incidence and severity were analyzed using Excel and Minitab 16 (version 2010). CMD incidences were expressed as percentages and values were arcsinetransformed [17] to facilitate logistic regression. We

\section{a}

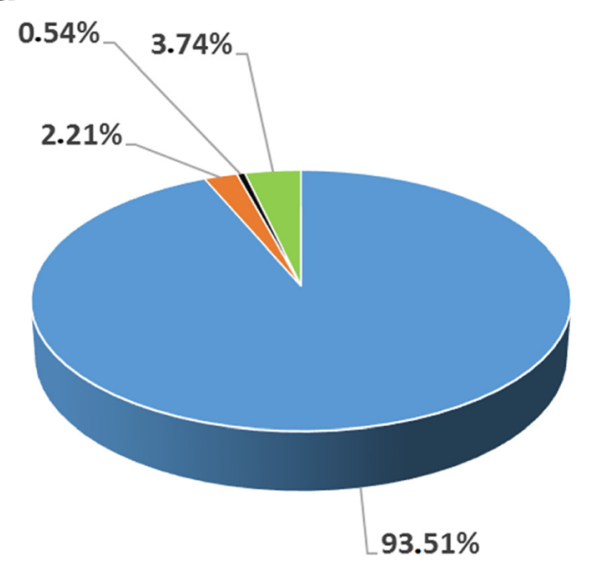

- Neighboring field

abroad

- Certified production

center

- Purchased

b

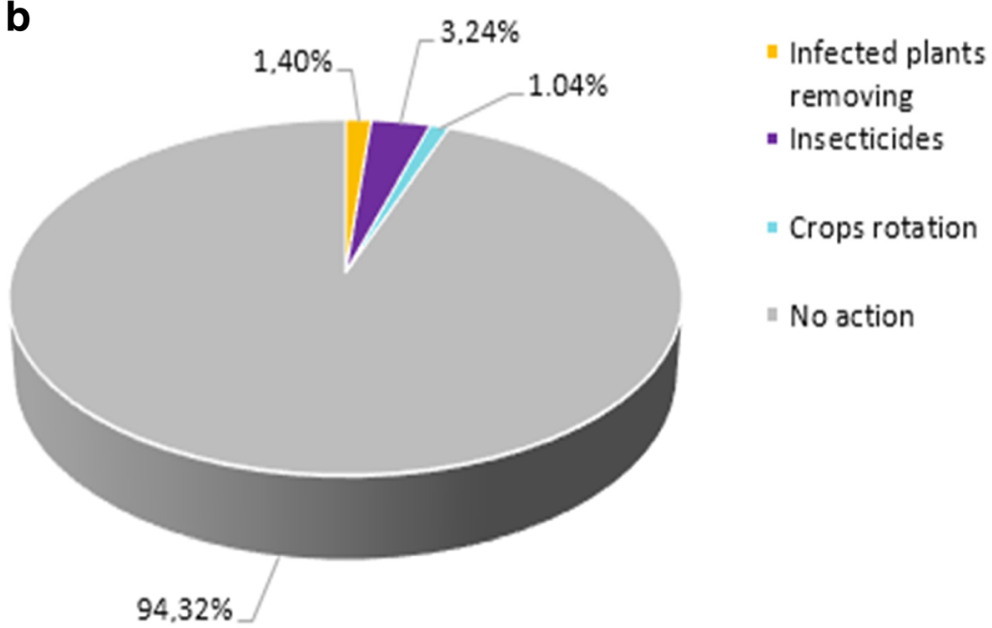

Fig. 2 Origins of cassava planting material reported by 369 surveyed farmers in Benin. a Origins of planting material, b disease management practices 
Table 4 Cultivars of cassava and the villages in which they are cultivated

\begin{tabular}{|c|c|}
\hline Cultivars & Villages \\
\hline Atinvovo & $\begin{array}{l}\text { Niaouli, Nouzounkpa, Agbodjédo, Agrimey, Kotto, } \\
\text { Koui, Ayou-centre, Haindé }\end{array}$ \\
\hline Hombètè & $\begin{array}{l}\text { Hounssagodo, Yokpodjèvié, Foncomè, } \\
\text { Soukpotomé, Haindé, Atchannou, Lizèmè, Tokpadji, } \\
\text { Hècondji, Médémahoué, Tokpoé, Houéglé, Comè, } \\
\text { Honvè, Ayou-centre, Agbodjèdo, Niaouli, } \\
\text { Nouzounkpa }\end{array}$ \\
\hline Ahôtonon & Dessounkpa, Lamè, Agrimey, Houéglé, Foncomè \\
\hline Awonliton & Ayou-centre \\
\hline $\mathrm{Rb}$ & Ayou-centre \\
\hline Ben & Ayou-centre \\
\hline Soukounon & Dovota, Dessounkpa, Lamè \\
\hline Adjatindaho & Agbodjedo, Koui \\
\hline Illakè & Nouzounkpa, Yokpodjèvié, Hounssagodo \\
\hline Sèguè & Yokpodjèvié, Nouzounkpa, Hounssagodo, Tokpoé \\
\hline Dossi & Ayou-centre, Hounssagodo \\
\hline Globokouté & Hounssagodo \\
\hline Bassi & Yokpodjèvié, Hounssagodo \\
\hline Limouti & Hounssagodo, Ayou-centre \\
\hline Agric-rouge & $\begin{array}{l}\text { Honvè, Comè, Atadocomè, Houéglé, Avègodo, } \\
\text { Tokpoé, Massè, Lizèmè, Atchannou, Haindé, } \\
\text { Hècondji, Tokpoé, Foncomè, Gouhoun, Honton, } \\
\text { Soukpotomè, Médémahoué }\end{array}$ \\
\hline Sowé & Dovota, Lamè, Dessounkpa, Koui \\
\hline Carder & Nouzoukpa \\
\hline Bonoua & Agrimey \\
\hline Gbégo & Agrimey, Koui \\
\hline Gbézé & Agrimey, Foncomè \\
\hline Dodo & Agrimey, Koui \\
\hline Alaboukoun & Koui \\
\hline Odohoungbo & Haindé \\
\hline Dogué & Koui \\
\hline Doukoui & Agrimey, Koui \\
\hline Gologoun & Nouzounkpa, Hounssagodo, Yokpodjèvié \\
\hline Kpèkè & Agbodjèdo \\
\hline Flèkè & $\begin{array}{l}\text { Niaouli, Agbodjèdo, Yokpodjèvié, Hounssagodo, } \\
\text { Ayou-centre }\end{array}$ \\
\hline Hata & Honvè, Soukpotomè, Lizèmè \\
\hline Agblehoundo & $\begin{array}{l}\text { Honvè, Comè, Tokpoé, Gouhoun, Honton, } \\
\text { Soukpotomè, Médémahoué, Haindé, Hècondji, } \\
\text { Tokpadji, Massè, Lizèmè, Soukpotomè }\end{array}$ \\
\hline Yovovi & Honton \\
\hline Agbézi & Foncomè, Gouhoun, Honton \\
\hline Ahôtonongbadji & Foncomè, Honton \\
\hline Gbendokoutouti & Foncomè \\
\hline Abatouin & Honton, Foncomè \\
\hline Houèton-kotou & Nouzounkpa, Niaouli, Agbodjèdo, Hounssagodo \\
\hline
\end{tabular}

Table 4 Cultivars of cassava and the villages in which they are cultivated (Continued)

\begin{tabular}{ll}
\hline Cultivars & Villages \\
\hline Atinwéwé & Agrimey, Kotto, Ayou, Haindé \\
Codjovi & Tokpoé, Massè, Tokpadji \\
Gbakaya & Houéglé, Avègodomè, Tokpoé, Tokpadji, Massè \\
Globo & Tokpoé, Massè \\
Sikuwé & Tokpoé \\
Ahokpo & Atadomè, Avègodomè, Atchannou \\
Gaciagamè & Atadomè, Houéglé, Avègodomè, Haindé \\
Acrakouté & Haindé \\
Koyinvo & Comè \\
Détahouboto & Foncomè \\
Zannou & Atadomè \\
Ouémènou & Atadomè, Médémahoué, Haindé \\
Doubokou & Agrimey, Koui \\
Gimgbo & Atadomè \\
Kalaba & Houéglé \\
Houla & Agrimey \\
\hline
\end{tabular}

performed a clustering analysis using multiple correspondence analysis (MCA) to group townships by mean severity class.

\section{Results}

Socio-demographic characteristics of surveyed farmers

Table 2 provides the socio-demographic characteristics of the 369 farmers surveyed. All the farmers surveyed were cassava famers. Most farmers surveyed were male $(62.40 \%)$. The majority of farmers $(94.10 \%)$ were $\geq 30$ years old and most (96.50\%) were married. Most cassava farmers $(74.90 \%)$ had no schooling. The majority $(66.20 \%)$ of farmers reported that they have had at least 30 years of experience in cassava production. This broad representation suggests that our random sampling method accounts for the demographics in these areas.

\section{Recognition of cassava mosaic disease}

All 369 farmers were able to recognize CMD in the photos provided during the survey. A chi-squared test suggested that recognition of CMD symptoms did not depend on a farmer's age, gender, education, or years of experience with cassava (Table 3). However, 98.60\% of farmers reported that they did not know the causes and vectors of CMD. Most (62.43\%) farmers said that they believe CMD reduces yields; $37.57 \%$ reported that they believe, based on their observations in their fields, that CMD prevents cassava from rooting. 
Table 5 Preferred cultivars by township

\begin{tabular}{lll}
\hline Townships & Number of cultivars & Preferred cultivars \\
\hline Zè & 13 & ${ }^{* *}$ Hombètè, ${ }^{* *}$ Atinwéwé \\
Allada & 13 & ${ }^{* *}$ Atinwéwé \\
Agbangnizoun & 3 & ${ }^{* *}$ Soukounon \\
Zogbodomey & 13 & ${ }^{* *}$ Atinwéwé \\
Dogbo & 13 & ${ }^{* * *}$ Agbézi, ${ }^{* *}$ Agric-rouge \\
Bopa & 10 & ${ }^{* *}$ Agblehoundo \\
Athiémé & 9 & ${ }^{* *}$ Agric-rouge \\
Houéyogbé & 12 & ${ }^{* * * A g r i c-r o u g e, ~}{ }^{* *}$ Agblehoundo \\
Comè & 8 & ${ }^{* *}$ Agblehoundo, ${ }^{* *}$ Agric-rouge
\end{tabular}

***Highly preferred (cited as preferred by at least $75 \%$ of farmers in township); ** moderately preferred (cited as preferred by at least $50 \%$ of farmers in township)

\section{Origins of plantation material and farmer action against CMD}

Almost all of the 369 farmers surveyed (93.51\%) reported that they obtain planting material from neighboring fields and use the same material over many seasons. A minority of farmers $(0.54 \%)$ acquired planting material from research centers, such as the National Institute of Agricultural Research of Benin (INRAB) and the Regional Center of Agricultural and Rural Development (CARDER) or from abroad (Fig. 2a). Analysis of independence revealed that the source of planting material was significantly related to $\operatorname{AEZ}\left(\chi^{2}=49.32, P=0.001\right)$.

A lack of CMD control measures was noted through the study. Only $1.4 \%$ of interviewed farmers took action to destroy plants infected with CMD (Fig. 2b). Only 3. $2 \%$ of farmers used insecticides to control insects such as whitefly and mites (Fig. 2b). In contrast, we found that of the 21 farmers who had been sensitized to CMD, 5 took action to destroy infected plants.

\section{Criteria for selection of cassava cultivars}

We recorded 52 unique cultivars (Table 4), of which 6 were preferred cultivars by at least $50 \%$ of the farmers (Table 5 ). The survey revealed that farmers prioritize the following characteristics when selecting cassava cultivars: yield, the quality of products resulting from the processing of cassava (gari, ethanol), the precocity of the cultivar, and taste (organoleptic quality). A chi-squared test showed that a farmer's preferred characteristics for cassava cultivars were significantly related to the AEZ in which he/she lived $\left(\chi^{2}=\right.$ 58.84, $\mathrm{ddl}=8, \quad P=0.01 \%)$. A separate chi-squared test showed that a farmer's preferred characteristics were also significantly related to a farmer's preferred cultivar $\left(\chi^{2}=\right.$ 129.09, $\mathrm{ddl}=68, \quad P=0.01)$. This dependence between choice criteria and preferred cultivars is explained by the

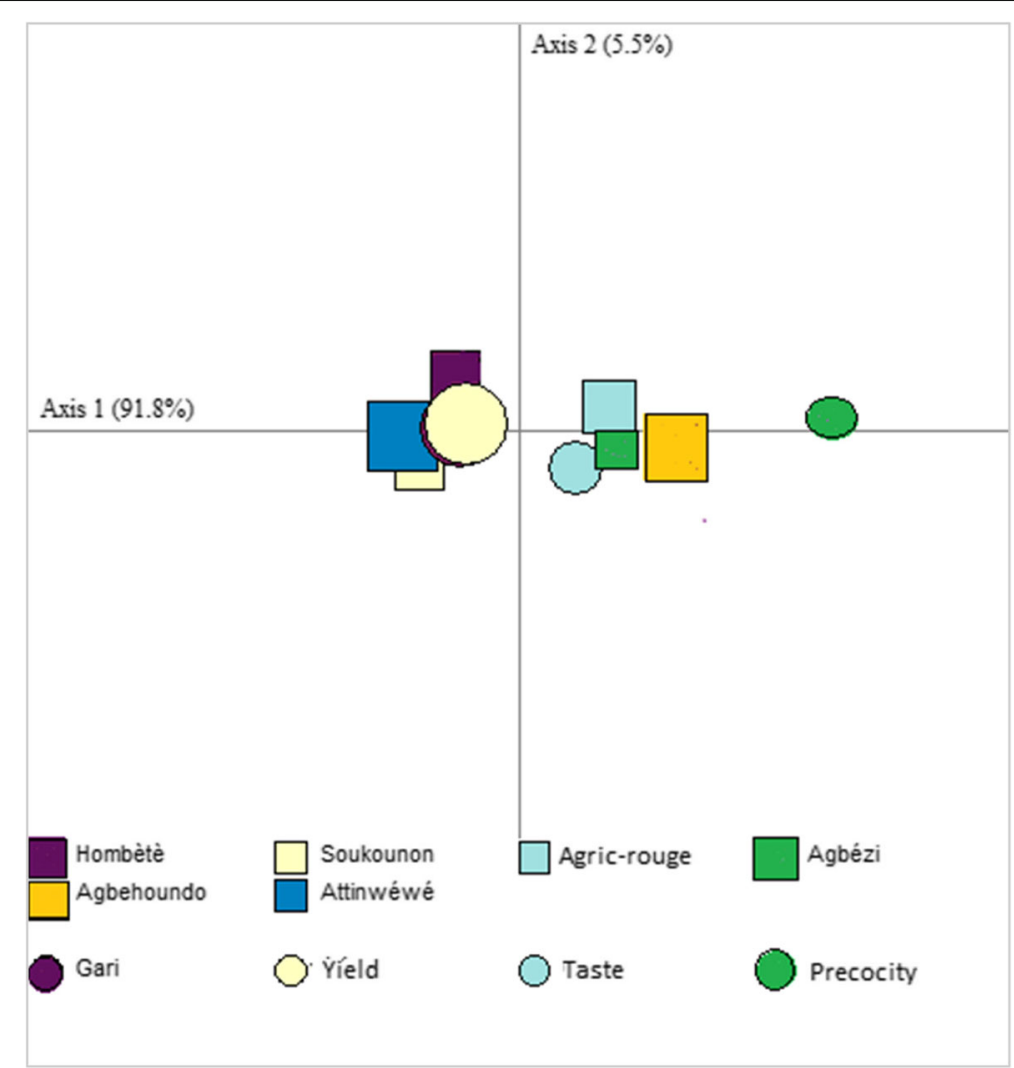

Fig. 3 Correspondence analysis grouping of preferred cultivars by township and farmers' four most important criteria (gari, yield, taste, and precocity) 


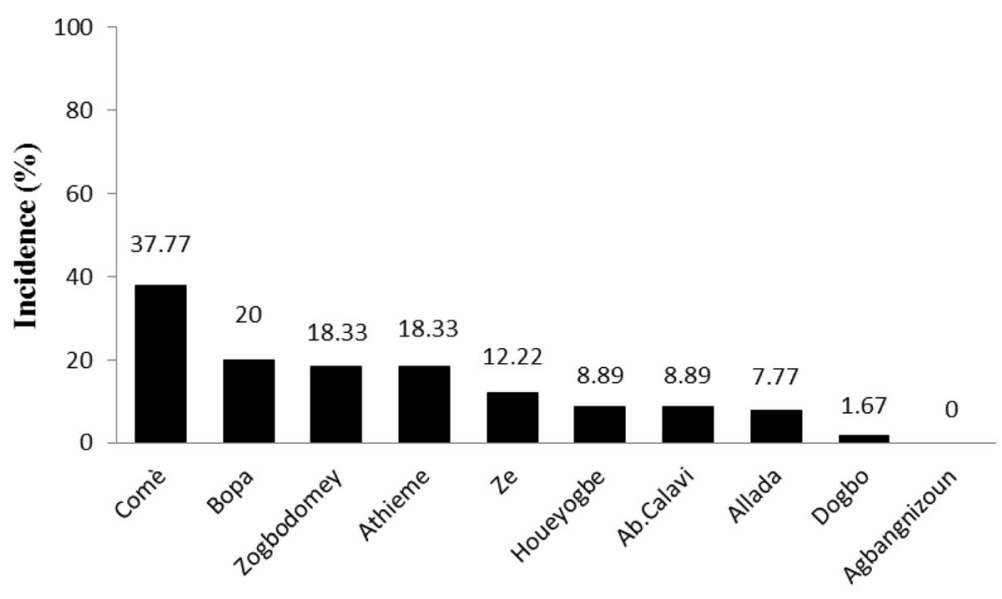

Townships

Fig. 4 Incidence of cassava mosaic disease by township in Benin

CA (Fig. 3). The inertia of two axes (97.3\%) shows that the CA summarizes all factors expressed. Soukounon, Atinwéwé, and Agbézi cultivars were preferred because of yield and early maturity, whereas Agric-rouge, Hombètè, and Agblehoundo cultivars were preferred because of their taste and gari (Fig. 3).

\section{Incidence of CMD}

The assessment of CMD incidence by township showed that Comè was the most affected township (37.77\%) followed by Bopa (20\%), Athiémé and Zogbodomey (18. $33 \%)$, Zè (12.22\%), Abomey-Calavi and Houéyogbé (8. 89\%), Allada (7.77\%), Dogbo (1.67\%), and Agbangnizoun (no reported cases). Among the three AEZ studied, disease incidence was highest in AEZ VIII (26.33\%) followed by AEZ VII (18.33\%) and AEZ VI (6.57\%), (Figs. 4 and 5). Chi-squared tests showed that differences in the distribution of CMD were more significant by AEZ than by township $(P<0.001)$ (Table 6$)$. Therefore, sampling in AEZ explained better the distribution of CMD in the study area. Binary logistic regression (Table 7) showed that disease incidence in AEZ VIII, AEZ VI, and Comè township was significantly higher than in AEZ VII and the other townships $(P<0.001)$.

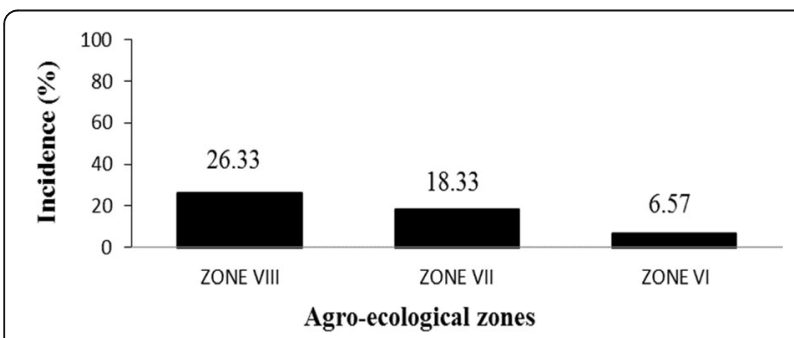

Fig. 5 Incidence of cassava mosaic disease by agro-ecological zone in Benin

\section{Severity of CMD}

Townships differed significantly $(P<0.001)$ in disease severity (Table 8 ). We used MCA to group townships by mean severity class: group A was townships dominated by severity score 1 (healthy plants), group B was townships dominated by severity score 2, group $\mathrm{BC}$ was townships dominated by severity score $3-4$, and group $C$ was townships dominated by severity score 5 (most diseased). Disease severity was highest in Comè and Bopa (Fig. 6). The townships Houéyogbé, Athiémé, Abomey-Calavi, Zè, Zogbodomey, and Agbangnizoun were less affected compared to Comè. MCA showed that the townships of Agbangnizoun, Dogbo, Zè, and Allada and the disease severity class [1; 2[were positively correlated to axis 1 in contrast to townships of Comè, Bopa and disease severity class [4; 5[, which were negatively correlated. Houéyogbé, Athiémé and Abomey-Calavi with disease severity class [2, 3[were positively correlated to axis 2 (Fig. 6).

\section{Discussion}

The results of this study showed that farmers in Benin can identify CMD by photographs because they have seen the disease in their fields and know that these symptoms constitute diseased plants. However, Benin farmers generally lack critical knowledge about CMD, its transmitting vectors, and how it can be controlled. We believe this lack of knowledge constitutes the major obstacle for CMD

Table 6 Chi-squared test of the distribution of CMD

\begin{tabular}{lllll}
\hline & ddl & $\log ^{-}$ & $x^{2}$ & $P$ \\
\hline Ord. Orig. & 1 & -330.91 & & \\
Agro-ecological zone & 2 & -313.35 & 35.11 & $2.37 \mathrm{E}-08$ \\
Township & 6 & -298.81 & 29.08 & $5.87 \mathrm{E}-05$ \\
Zone*township & 0 & -298.81 & 0.00 & $3.00 \mathrm{E}+30$ \\
\hline
\end{tabular}

* means interaction 
Table 7 Logistic regression by township and agro-ecological zone

\begin{tabular}{lllllll}
\hline & Level & Column & Estimation & Standard & Wald & $P$ \\
\hline Ord. Orig & & 1 & -7.05 & 0.57 & 151.05 & 0.00 \\
Zone & Zone VI & 2 & 4.72 & 0.86 & 30.11 & 0.00 \\
Zone & Zone VIII & 3 & 5.08 & 0.71 & 51.41 & 0.00 \\
Township & Houeyogbe & 5 & 0.00 & 0.52 & 0.00 & 1.00 \\
Township & Dogbo & 6 & -1.75 & 1.07 & 2.65 & 0.10 \\
Township & Allada & 7 & -0.15 & 0.54 & 0.07 & 0.79 \\
Township & Zè & 8 & 0.36 & 0.49 & 0.53 & 0.47 \\
Township & Comè & 10 & 1.47 & 0.39 & 14.38 & 0.00 \\
Township & Bopa & 11 & 0.59 & 0.39 & 2.20 & 0.14 \\
\hline
\end{tabular}

control in Benin. Farmers who were sensitized and trained to identify the manifestations of the disease could differentiate diseased and healthy plants. These few farmers who were familiar with CMD reported that they were sensitized to it by rural development agents. Our survey results suggests that farmers could be sensitized and trained by researchers and farming agents on the symptoms of $\mathrm{CMD}$, thus giving them the ability to take proper action to control the disease in their own fields and minimize its spread to neighboring fields. These observations were in accordance with those obtained by Chikoti et al. [8], who also found that the lack of CMD knowledge by farmers requires researchers and extension agents to sensitize and train farmers. In our study, we found that the few farmers who had been sensitized to CMD took action to destroy infected plants and used insecticides to control whitefly, mites, and other insects. Thus, we recommend that training be widely implemented in CMD-prone areas to give these farmers the knowledge and tools to take control measures as soon as the disease is identified.

Our study identified cultivars in each AEZ that are preferred by farmers, which provides an opportunity for these preferred cultivars to be screened for CMD resistance. The farmers generally preferred the precocious cultivars with good taste, high yields, good gari, and alcohol production. These observations are in agreement with those made by Njukwe et al. [18] who evaluated the farmers' preferred characteristics of cassava in Cameroon.

Table 8 Clustering of townships by class or degree of severity of CMD

\begin{tabular}{lllll}
\hline Classes & Size & Means & Groups & $P$ \\
\hline$[1,2[$ & 10 & 1.59 & A & $0.00^{* * *}$ \\
{$[2,3[$} & 10 & 0.41 & B & \\
{$[3,4[$} & 10 & 0.36 & BC & \\
{$[4,5[$} & 10 & 0.20 & BC & \\
{$[5,-[$} & 10 & 0.13 & $C$ & \\
\hline
\end{tabular}

*** very high significant, ** high significant, * significant

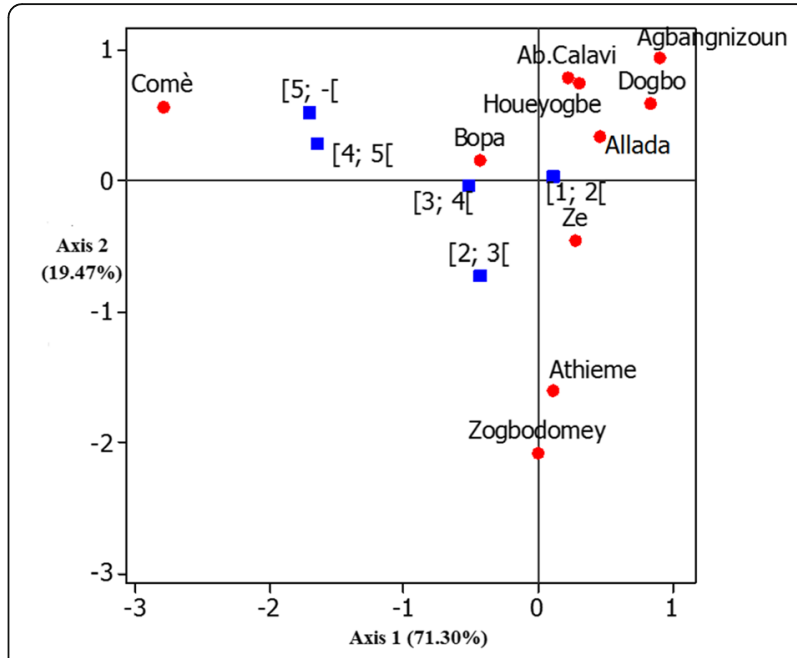

Fig. 6 Townships in Benin clustered by disease severity score for cassava mosaic disease. Blue squares denote disease severity classes. Red squares denote townships

Most farmers used planting materials from previous seasons or nearby fields. Consequently, they frequently replanted infected cuttings. CMD is a systemic infection; once it infects a cassava plant, it proliferates and all plants from its infected cuttings will be diseased. Using infected cuttings from previous seasons also increases the severity of the disease and favors the rapid expansion of the disease [19]. Farmers who are unaware that their planting material is infected further spread CMD by sharing cuttings with their neighbors. These farmers do not realize the impact of CMD on cassava yields nor do they recognize that neighboring (non-cassava) crops can harbor whitefly; thus, these whitefly-infested fields go untreated, and CMD is further spread from one field to another.

\section{Conclusion}

This study established that farmers in the three major AEZ of Benin already know how to recognize the symptoms of CMD but do not realize how CMD could affect cassava yields or how it could spread through the use of infected cuttings or the whitefly vector. We recommend that farmers receive training by researchers on the disease so that farmers can implement adequate control measures when CMD is identified. Across all surveyed areas, we identified six preferred cultivars based on the four most commonly stated preference criteria (precocity, yield, gari, and taste). Our results suggest that farmers will be more likely to use CMD-resistant cultivars and clean plant material if those cultivars meet farmers' existing preference criteria. This constitutes the best long-term solution to CMD, because if farmers use and disseminate CMD-resistant cultivars, yield losses will be reduced even if farmers lack knowledge about the disease. Thus, to ensure that CMD-resistant cultivars 
are integrated, we suggest that cultivar recommendations be strategically aligned with the characteristics desirable to cassava farmers in each region.

\section{Abbreviations}

AEZ: Agro-ecological zones; CARDER: Centre d'Action Régional pour le Développement Rural; CMD: Cassava mosaic disease; INRAB: Institut National de recherche Agricole du Benin; WAVE: West African Virus Epidemiology

\section{Acknowledgements}

The authors thank the Ministry of Higher Education and Scientific Research of Benin through the fund of supporting PhD students. We thank also the WAVE (West Africa Virus Epidemiology) program funded by the Bill \& Melinda Gates Foundation for additional financial support. We also wish to express our gratitude to the cassava farmers who took the time to participate in this survey

\section{Availability of data and materials}

All data generated or analyzed during this study are included in this published article (and its supplementary information files).

\section{Authors' contributions}

JAH, Z-TM, and CA designed the study; Z-TM and CA supervised the research; JAH and EAEA conducted the fieldwork; EAEA analyzed the data; JSP designed the study; and JAH and GHTC wrote the manuscript. All authors read, corrected, and approved the manuscript.

\section{Ethics approval and consent to participate}

Before conducting interviews, prior informed consent was obtained from all participants. No further ethics approval was required.

\section{Competing interests}

The authors declare that they have no competing interest.

\section{Publisher's Note}

Springer Nature remains neutral with regard to jurisdictional claims in published maps and institutional affiliations.

\section{Author details}

${ }^{1}$ Central Laboratory of Plant Biotechnology and Plant Breeding, Department of Genetics and Biotechnology, Faculty of Science and Technique, University of Abomey - Calavi, Abomey-Calavi, Benin. 'Laboratory of Plant Physiology, Université Felix Houphouët-Boigny, Abidjan, Côte d'Ivoire. 'aboratory of Molecular Plant Pathology, School of Horticulture and Green Space, National University of Agriculture, Porto-Novo, Benin.

Received: 21 November 2017 Accepted: 2 April 2018

Published online: 25 April 2018

\section{References}

1. Kehinde AT. Utilization potentials of cassava in Nigeria: the domestic and industrial products. Food Rev Intl. 2006;22:29-42.

2. Aduni UA, Ajayi OA, Bokanga M, Dixon BM. The use of cassava leaves as food in Africa. Ecol Food Nutr. 2005:44:423-35.

3. Kombo GR, Dansi A, Loko LY, Orkwor GC, Vodouhè R, Assogba P, Magema JM. Diversity of cassava (Manihot esculenta Crantz) cultivars and its management in the department of Bouenza in the Republic of Congo. Genet Resour Crop Evol. 2012:59:1789-803.

4. Robooni T, Paul S, Rob M, Robert K. Combining ability analysis of storage root yield and related traits in cassava at the seedling evaluation stage of breeding. J Crop Improv. 2014;28:530-46.

5. Thresh JM, Otim-Nape GW, Legg JP, Fargette D. African cassava mosaic virus disease: the magnitude of the problem. AJRTC. 1997;2:13-8.

6. Storey HH, Nichols RFW. Studies of the mosaic diseases of cassava. Ann Appl Biol. 1938;25:790-806

7. Dubern J. La Mosaïque du manioc: bilan des connaissances actuelles, Rapport ORSTOU; 1976. p. 29

8. Chikoti PC, Melis R, Shanahan P. Farmer's perception of cassava mosaic disease, preferences and constraints in Lupaula Province of Zambia. Am J Plant Sci. 2016;7:1129-38.
9. Tumuhimbise R, Melis R, Shanahan P, Kawuki R. Farmers' perceptions on early storage root bulking in cassava (Manihot esculenta Crantz) in east and central Uganda and their implication for cassava breeding. World J Agric Sci. 2012:8:403-8.

10. Agwu $A E$, Anyaeche $C L$. Adoption of improved cassava varieties in six rural communities in Anambra State, Nigeria. Afr J Biotechnol. 2007;6:89-98.

11. Agre AP, Dansi A, Rabbi IY, Battachargee R, Dansi M, Melaku G, Augusto B, Sanni A, Akouegninou A, Akpagana K. Agromorphological characterization of elite cassava (Manihot esculenta Crantz) cultivars collected in Benin. Int J Curr Res Biosci Plant Biol. 2015;2:1-14.

12. Dagnelie P. Statistiques théoriques et appliquées: statistique descriptive et bases de l'influence statistique. Paris et Brussels: De Boeck et Larcier; 1998.

13. Gnonlonfin GJB, Koudande DO, Sanni A, Brimer L. Farmers' perceptions on characteristics of cassava (Manihot esculenta Crantz) varieties used for chips production in rural areas in Benin, West Africa. Int J Biol Chem Sci. 2011:5:870-9.

14. Dansi A, Dantsey-Barry H, Agre AP, Dossou-Aminon I, Assogba P, Loko YL, N'Kpenu EK, Kombaté K, Dansi M, Vodouhè R. Production constraints and farmers' cultivar preference criteria of cultivated yams (Dioscorea cayenensis D. rotundata complex) in Togo. Int J Appl Biol Pharm Technol. 2013;4:191-9.

15. Mupenda KT et walangululu MJ. Status phytosanitary of cassava (Manihot esculenta (rantz) in rural area of South Kivu, western coast of Lake Kivu, Democratic Republic of Congo. Int J Innov Sci Res. 2016;20:180-7.

16. Hahn SK, Terry ER, Leuschner K. Breeding cassava for resistance to cassava mosaic disease. Euphytica. 1980;29:673-83.

17. Njock TE, Atiri GI, Thottappilly G, Hahn S. Distribution and disease recovery of African cassava mosaic virus (ACMV) in stems of resistant and susceptible cassava, Proceedings of $5^{\text {th }}$ symposium of ISTRC-AB; 1994. p. 149-52.

18. Njukwe E, Hanna R, Kirscht H, Araki S. Farmers perception and criteria for cassava variety preference in Cameroon. Afr Stud Monogr. 2013;34:221-34.

19. Ntawuruhunga P, Legg J, Okidi J, Okao-Okuja G, Tadu G, Remington T. Southern Sudan Equatorial Region. Cassava baseline survey technical report, IITA, Ibadan, Nigeria; 2007. p. 65.

\section{Ready to submit your research? Choose BMC and benefit from:}

- fast, convenient online submission

- thorough peer review by experienced researchers in your field

- rapid publication on acceptance

- support for research data, including large and complex data types

- gold Open Access which fosters wider collaboration and increased citations

- maximum visibility for your research: over $100 \mathrm{M}$ website views per year

At BMC, research is always in progress.

Learn more biomedcentral.com/submissions 